\title{
International
}

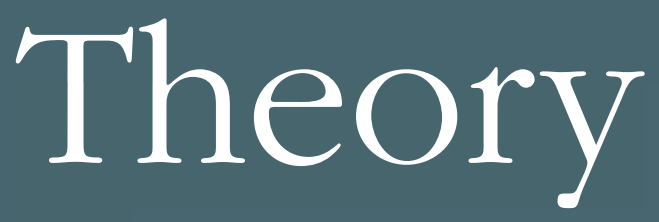

\section{A Journal of International Politics, Law and Philosophy}

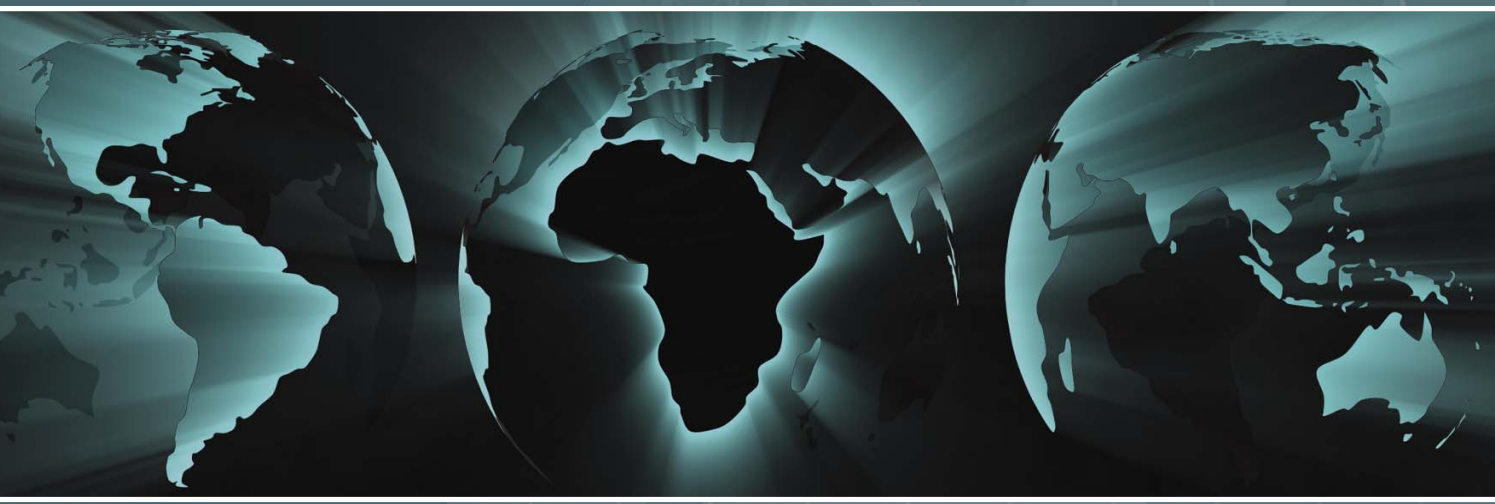

Aggression and the symmetrical application of International Humanitarian Law

Pablo Kalmanovitz

Norms, perverse effects, and torture

William L. d'Ambruoso

International norm polarization: sexuality as a subject of human rights

protection

Jonathan Symons and Dennis Altman

The co-originality of human rights and democracy in an international order

Johan Karlsson Schaffer

Triangulating territory: a case for pragmatic interaction between political science,

political geography, and critical IR

Burak Kadercan

Money and multilateralism: how funding rules constitute 10 governance

Erin R. Graham

The dilemma of informal governance with outside option as solution

Daniel Verdier 


\title{
International Theory \\ A Journal of International Politics, LaW and Philosophy www.journals.cambridge.org/it
}

\author{
EDITORS \\ Duncan Snidal, Nuffield College, Oxford \\ Alexander Wendt, Mershon Center for International Security Studies, Ohio State University \\ Christian Reus-Smit, University of Queensland, Australia \\ MANAGING EDITOR \\ Tim Luecke, Mershon Center for International Security Studies, Ohio State University
}

\section{EDITORIAL BOARD}

Kenneth Abbott, Arizona State University

Antony Anghie, University of Utah

James Bohman, Saint Louis University

Chris Brown, London School of Economics

and Political Science

Jutta Brunnée, University of Toronto

Hilary Charlesworth, The Australian

National University

Jack Donnelly, University of Denver

Raymond Duvall, University of Minnesota

Robyn Eckersley, University of Melbourne

Toni Erskine, UNSW Canberra

James Fearon, Stanford University

Jack Goldsmith, Harvard University
Ryan Goodman, New York University

Kimberley Hutchings, London School of

Economics and Political Science

Andrew Kydd, University of Wisconsin

Andrew Moravcsik, Princeton University

Iver Neumann, London School of Economics

V. Spike Peterson, University of Arizona

Sergei Prozorov, University of Helsinki

Gerry Simpson, London School of Economics

Jack Snyder, Columbia University

Neil Walker, University of Edinburgh

David A. Welch, University of Waterloo

Michael Williams, University of Ottawa

\section{STATEMENT OF Aims}

International Theory (IT) promotes theoretical scholarship about the positive, legal, and normative aspects of world politics respectively. IT is open to theory of all varieties and from all disciplines, provided it addresses problems of politics, broadly defined and pertains to the international.

IT welcomes scholarship that uses evidence from the real world to advance theoretical arguments. However, IT is intended as a forum where scholars can develop theoretical arguments in depth without an expectation of extensive empirical analysis.

IT's over-arching goal is to promote communication and engagement across theoretical and disciplinary traditions. IT puts a premium on contributors' ability to reach as broad an audience as possible, both in the questions they engage and in their accessibility to other approaches. However, IT is also open to work that remains within one scholarly tradition, although in that case authors must make clear the horizon of their arguments in relation to other theoretical approaches.

All articles will be peer-reviewed.

With thanks to the Mershon Center, Ohio State University, for financial support.

This journal issue has been printed on FSC-certified paper and cover board. FSC is an independent, non-governmental, not-for-profit organization established to promote the responsible management of the world's forests. Please see www.fsc.org for information. 


\section{CONTENTS}

1 Aggression and the symmetrical application of International Humanitarian Law

Pablo Kalmanovitz

33 Norms, perverse effects, and torture

William L. D’AmbRUOSO

61 International norm polarization: sexuality as a subject of human rights protection Jonathan Symons, Dennis Altman

96 The co-originality of human rights and democracy in an international order JOHAN KarLSSON SCHAFFER

125 Triangulating territory: a case for pragmatic interaction between political science, political geography, and critical IR

BURAK KADERCAN

162 Money and multilateralism: how funding rules constitute 10 governance

ERIN R. GRAHAM

195 The dilemma of informal governance with outside option as solution

DANIEL VERDIER 